\title{
Effects of Several Factors on the Monozygotic Twin Production in the Mouse
}

\author{
Minkang WANG*, Yoko KATO and Yukio TSUNODA \\ Laboratory of Animal Reproduction, College of Agriculture, and Research Institute for \\ Animal Developmental Biotechnology, Kinki University, Nara 631, Japan
}

\begin{abstract}
Monozygotic mouse twins were produced by micromanipulation of 2-cell stage embryos and factors affecting the embryonic development were examined. In experiment 1, 2-cell embryos obtained from superovulated CD-1 strain or F1 (C57BL/ $6 \times$ CBA) females mated with CD-1 strain males were separated into a single blastomere. Pairs of twin blastomeres were cultured with or without supplementation of growth factors, a mixture of IGF-1, TGF- $\beta$ and EGF for 3 days and twin blastocysts developed were transferred to recipient females. Of 174 pairs of F1 embryos, 88 to 100\% developed to twin blastocysts. In contrast, development of CD-1 embryos (835 pairs) was significantly lower (25 to $36 \%$ ). Of $63 \mathrm{~F} 1$ twin blastocysts transferred, 7 to $29 \%$ developed to twin fetuses, whereas only 0 to $8 \%$ of 62 pairs of CD-1 embryos developed to twins. In experiment 2 , one nucleus of a 2-cell stage F1 embryo was electrically fused with an enucleated recipient 2-cell embryo. The 2-cell embryo from which a nucleus was removed was cultured together with the reconstituted embryo as a monozygotic twin pairs. Of 24 and 28 twin pairs cultured with or without growth factors, 92 and $86 \%$ developed to twin blastocysts, respectively. After transfer of 13 twin blastocysts to recipients, 3 and 2 twin fetuses were obtained. These findings indicated that monozygotic twin mice can be produced more efficiently from F1 embryos than from CD-1 embryos. Methods of removal of zona pellucida and addition of growth factors to the culture medium had no effect on the efficiency of production of monozygotic twins.

Key words: Monozygotic twin mice, Growth factors, Nuclear transfer.
\end{abstract}

(J. Reprod. Dev. 43: 91-95, 1997)

M onozygotic twin mice are useful as a good animal model for various basic studies, since monozygotic twins have a greater degree of similarity than dizygotic twins even in inbred strains of mice [1]. The success rate for the production of monozygotic twin mice is generally low [2-6]. In goats, sheep and cattle, relatively high success rates have been obtained by simply bisecting compacted morulae or blastocysts into halves and transferring them to recipients [7-9]. Since the mouse blastocysts have a small number of cells

Accepted for publication: January 13, 1997

Correspondence: $Y$. Tsunoda

*Present address: Department of Biology, Yunnan College of Education, Kunming 650223, P.R. China and the implantation window is narrow, bisected mouse embryos which have less than half the normal number of cells do not have enough time to increase the number of cells for normal development to term [10]. Monozygotic twin mice have been produced by splitting 2-cell [2-4, 6], 8-to 16cell [4] and decompacted morula [5] stage embryos into a pair of half embryos and culturing them in vitro prior to transfer to recipients. The twining rates of half embryos reported in the previous works varied from $0 \%[2,10]$ to $56 \%$ [3], respectively. Although twin blastocysts developed in the ligated mouse oviduct had high ability to developed to young [4], a skillful technique was required. Recently, it has been reported that trans- 
plantation of a single nucleus from 2-cell embryos into an enucleated blastomere of a 2-cell embryo produces monozygotic twin mice efficiently [11].

A single twin pair, derived from one embryo, must be cultured individually for the production of monozygotic twin mice. Culture of embryos singly has been reported to decrease the ability to develop to blastocysts [12] and to young [13]. On the other hand, growth factors such as IGF-1 [14], EGF and TGF- $\beta$ [12] stimulate the in vitro development of mouse embryos cultured singly. However, the effects of such growth factors on the developmental ability of embryos having half the normal number of blastomeres are unknown. The effects of several factors on the success rates to produce monozygotic twin mice were examined.

\section{Materials and Methods}

\section{Experiment 1}

The effects of the following factors on the developmental ability of twin blastomeres of 2-cell embryos in vitro and after transfer to recipients were examined; female strain used, method to remove zona pellucida and addition of growth factors to culture medium. Two-cell embryos were collected from superovulated albino CD-1 strain or agouti F1 (C57BL / $6 \times$ CBA) females mated with CD-1 strain males $45 \mathrm{~h}$ after hCG injection using M2 medium [15]. Zonae pellucidae of embryos were removed enzymatically with $0.5 \%$ pronase or mechanically by micromanipulation [4]. Zona free 2-cell embryos were separated into single blastomeres. A pair of twin blastomeres was cultured in a $20 \mu \mathrm{l}$ droplet of M16 medium [16] with or without growth factors for 3 days at $37 \mathrm{C}$ in an atmosphere of $95 \%$ air and $5 \% \mathrm{CO}_{2}$ in a Nunk plastic dish. The growth factors used were the mixture of IGF-1 (Sigma, $4 \mathrm{ng} / \mathrm{ml}$ ), TGF- $\beta$ (Sigma, $2 \mathrm{ng} /$ $\mathrm{ml}$ ) and EGF (Sigma, $4 \mathrm{ng} / \mathrm{ml}$ ). Twin embryos developed to blastocysts with or without growth factors were transferred to each oviduct of the same recipients of Day 1 pregnant CD-1 females mated with CD-1 (for non-albino donor embryos) or F1 (for albino donor embryos) males. The fetuses originated from transferred embryos were determined by their eye color. All recipients were killed on Day 17.5 of pregnancy, and the weights of live fetuses and placentas were measured.

\section{Experiment 2}

By using the following original procedure to produce twin embryos, the effect of growth factors on the monozygotic twin production was examined. Donor and recipient 2-cell embryos were recovered $45 \mathrm{~h}$ after hCG injection from superovulated F1 females mated with CD-1 males. A small cut was made in the zona pellucida and embryos were placed in a small drop of M2 medium supplemented with $10 \%$ FCS, $5 \mu \mathrm{g} / \mathrm{ml}$ cytochalasin B and 3 $\mu \mathrm{g} / \mathrm{ml}$ nocodazole. Nuclei of recipient embryos were removed from both blastomeres. One nucleus from each donor embryo was aspirated into an enucleation pipette and inserted into the perivitelline space of recipient embryos to fuse with one blastomere [11]. The nucleus was fused with an enucleated blastomere by two DC pulses of 0.75 $\mathrm{KV} / \mathrm{cm}$ for $50 \mu \mathrm{sec}$ in Zimmerman medium [17]. Embryos whose blastomeres were fused with each other were discarded. The remaining blastomere nucleus of the donor embryo was left intact, and was cultured together with the reconstituted embryo as one twin pair in $20 \mu 1$ M16 medium with or without growth factors for 3 days as described in experiment 1 .

A single set of twin blastocysts developed in M16 medium without growth factors was transferred to one oviduct of Day 1 pregnant CD-1 females mated with CD-1 males. The other oviduct received a single set of twin blastocysts developed in the medium with growth factors. All recipients were killed on Day 17.5 of pregnancy and the weights of live fetuses and placentas were measured.

The statistical significance of the results in both experiments was examined by $\chi^{2}$ test or Student's $t$ test (for body and placenta weights).

\section{Results}

As shown in Table 1, the most marked effect on the developmental ability of a single blastomere was observed when the embryos were collected from F1 females. Although the developmental ability to blastocysts of a single blastomere of 2-cell embryos from CD-1 females was low (34 to $44 \%$ ), most of them obtained from F1 embryos (93 to $100 \%$ ) developed to blastocysts. The proportion of twin pairs that developed to blastocysts was also 
Table 1. The viability of mouse twin blastomeres produced from 2-cell embryos in vitro

\begin{tabular}{cccccc}
\hline Female & $\begin{array}{c}\text { Method to } \\
\text { remove zona } \\
\text { pellucida }\end{array}$ & $\begin{array}{c}\text { With (+) or } \\
\text { without }(-) \\
\text { growth factors }\end{array}$ & $\begin{array}{c}\text { No. of blastomeres } \\
\text { [No. of twin pairs] } \\
\text { cultured }\end{array}$ & $\begin{array}{c}\text { No. of blastomeres } \\
\text { developed to } \\
\text { blastocysts }(\%)\end{array}$ & $\begin{array}{c}\text { No. of twin pairs } \\
\text { developed to } \\
\text { blastocysts }(\%)\end{array}$ \\
\hline CD-1 & Pronase & + & $480[240]$ & $161(34)^{\mathrm{b}}$ & $61(25)^{\mathrm{b}}$ \\
F1 & Mechanical & - & $522[261]$ & $229(44)^{\mathrm{a}}$ & $94(36)^{\mathrm{a}}$ \\
& Pronase & - & $314[157]$ & $132(42)^{\mathrm{a}}$ & $56(36)^{\mathrm{a}}$ \\
& & + & $354[177]$ & $141(40)^{\mathrm{a}}$ & $62(35)^{\mathrm{a}}$ \\
& Mechanical & - & $86[43]$ & $86(100)^{\mathrm{c}}$ & $43(100)^{\mathrm{c}}$ \\
& & - & $90[45]$ & $86(96)^{\mathrm{c}}$ & $43(96)^{\mathrm{c}}$ \\
& & - & $84[42]$ & $78(93)^{\mathrm{c}}$ & $37(88)^{\mathrm{c}}$ \\
\hline
\end{tabular}

Values with different superscripts in the same column differ significantly $(\mathrm{P}<0.05)$.

Table 2. Developmental ability of mouse twin blastocysts after transfer to recipients

\begin{tabular}{ccccccc}
\hline Female & $\begin{array}{c}\text { Method to } \\
\text { remove zona } \\
\text { pellucida }\end{array}$ & $\begin{array}{c}\text { With (+) or } \\
\text { without }(-) \\
\text { growth factors }\end{array}$ & $\begin{array}{c}\text { No. of embryos } \\
\text { [No. of twin pairs] } \\
\text { transferred }\end{array}$ & $\begin{array}{c}\text { No. of live } \\
\text { young (\%) [No. of } \\
\text { twin pairs (\%)] }\end{array}$ & $\begin{array}{c}\text { Body weight } 1) \\
\text { of young (g) } \\
\text { Mean } \pm \text { S.D. }\end{array}$ & $\begin{array}{c}\text { Placenta1) } \\
\text { weight (g) } \\
\text { Mean } \pm \text { S.D. }\end{array}$ \\
\hline CD-1 & Pronase & + & $28[14]$ & $5(18)^{\mathrm{b}}[1(7)]$ & $1.25 \pm 0.24$ & $0.23 \pm 0.05$ \\
& & - & $34[17]$ & $6(18)^{\mathrm{b}}[1(6)]$ & $0.93 \pm 0.38$ & $0.17 \pm 0.01$ \\
F1 & Pronase & + & $36[18]$ & $8(22)^{\mathrm{b}}[0(0)]$ & $0.84 \pm 0.32$ & $0.19 \pm 0.03$ \\
& & + & $26[13]$ & $4(15)^{\mathrm{b}}[1(8)]$ & $1.03 \pm 0.09$ & $0.20 \pm 0.02$ \\
& Mechanical & - & $42[21]$ & $20(48)^{\mathrm{a}}[6(29)]$ & $1.02 \pm 0.22$ & $0.19 \pm 0.06$ \\
& & - & $28[14]$ & $12(43)^{\mathrm{a}}[4(29)]$ & $1.03 \pm 0.11$ & $0.20 \pm 0.07$ \\
& & - & $26[13]$ & $8(31)^{\mathrm{ab}}[2(15)]$ & $1.00 \pm 0.21$ & $0.20 \pm 0.03$ \\
\end{tabular}

Values with different superscripts in the same column differ significantly $(\mathrm{P}<0.05)$.

1)The statistical significance in body weight and placenta weight was compared between with and without growth factors.

higher in the F1 groups (88 to $100 \%$ ) than in the CD-1 groups ( 25 to $36 \%$ ). Method for removing zona pellucida from donor embryos had no effect on the developmental ability of the blastomere. In a preliminary experiment, the effects of IGF (concentrations were 4,10 or $20 \mathrm{ng} / \mathrm{ml})$, TGF- $\beta(2,5$ or $10 \mathrm{ng} / \mathrm{ml})$, EGF $(4,10 \mathrm{or} 20 \mathrm{ng} / \mathrm{ml})$ or mixture of 4 $\mathrm{ng} / \mathrm{ml} \mathrm{IGF,} 2 \mathrm{ng} / \mathrm{ml}$ TGF- $\beta$ and $4 \mathrm{ng} / \mathrm{ml}$ EGF at the ratio of 1:1:1 on the developmental ability of a single blastomere of 2-cell embryos recovered from the CD-1 strain were examined. Since the proportion of blastocysts developed was higher after culture in the presence of the mixture of growth factors $(71 \%)$ than in other groups with single treatment (36 to $62 \%$ ), the mixture of $4 \mathrm{ng} / \mathrm{ml} \mathrm{IGF,} 2$ $\mathrm{ng} / \mathrm{ml}$ TGF- $\beta$ and $4 \mathrm{ng} / \mathrm{ml}$ EGF was used in the present study. As shown in Table 1, the addition of growth factors had no significant effect on the development of single blastomeres in vitro.

As shown in Table 2, the developmental rate to fetuses was higher in blastocysts obtained from F1 donors (23 to $48 \%$ ) than those obtained from CD-1 donors (15 to $22 \%$ ). The methods to remove the zona pellucida and to culture embryos with or without growth factors in the culture medium did not significantly affect the ability of twin blastocysts to develop to fetuses. There were no significant differences either in the body weight or in the placenta weight among the groups. Finally, $3(5 \%)$ and $13(21 \%)$ monozygotic twins were produced after transfer of 62 sets (from CD-1 donor) and 63 sets (from F1 donor) of twin blastocysts, respectively.

The development of twin pair embryos produced by nuclear transfer in vitro and the ability of embryos after transfer to recipients are shown in Table 3. The proportion of embryos that developed to blastocysts in the medium supplemented with growth factors $(96 \%)$ was not different from that obtained without growth factors $(91 \%)$, and after transfer of the twin blastocysts to recipients, 38 and $35 \%$ of them developed to fetuses, respective- 
Table 3. In vitro and in vivo development of twin embryos produced by nuclear transfer

\begin{tabular}{|c|c|c|c|c|c|c|}
\hline $\begin{array}{c}\text { With }(+) \text { or } \\
\text { without }(-) \\
\text { growth factors }\end{array}$ & $\begin{array}{c}\text { No. of embryos } \\
\text { [No. of twinpairs] } \\
\text { cultured }\end{array}$ & $\begin{array}{l}\text { No. of embryos } \\
\text { [No. of twin } \\
\text { pairs }(\%)] \\
\text { developed to } \\
\text { blastocysts }(\%)\end{array}$ & $\begin{array}{l}\text { No. of embryos } \\
\text { [No. of twin } \\
\text { pairs] } \\
\text { transferred }\end{array}$ & $\begin{array}{l}\text { No. of live } \\
\text { young (\%) } \\
\text { [No. of twin } \\
\text { pairs }(\%)]\end{array}$ & $\begin{array}{l}\text { Body weight } \\
\text { of young }(\mathrm{g}) \\
\text { Mean } \pm \text { S.D. }\end{array}$ & $\begin{array}{c}\text { Placenta } \\
\text { weight }(\mathrm{g}) \\
\text { Mean } \pm \text { S.D. }\end{array}$ \\
\hline+ & $\begin{array}{c}48 \\
{[24]}\end{array}$ & $\begin{array}{c}46(96) \\
{[22(92)]}\end{array}$ & $\begin{array}{c}26 \\
{[13]}\end{array}$ & $\begin{array}{l}10(38) \\
{[3(23)]}\end{array}$ & $1.01 \pm 0.14$ & $0.22 \pm 0.05$ \\
\hline - & $\begin{array}{c}56 \\
{[28]}\end{array}$ & $\begin{array}{c}51(91) \\
{[24(86)]}\end{array}$ & $\begin{array}{c}26 \\
{[13]}\end{array}$ & $\begin{array}{c}9(35) \\
{[2(15)]}\end{array}$ & $1.00 \pm 0.18$ & $0.23 \pm 0.06$ \\
\hline
\end{tabular}

ly. There was no significant difference either in the body weight of fetuses or in the placenta weight between the two groups. Together with these groups, $5(19 \%)$ sets of monozygotic twins were obtained after transfer of 26 sets of twin blastocysts.

\section{Discussion}

The developmental ability of twin mouse embryos was markedly influenced by the difference of the strain of embryo. Most of the half embryos derived from F1 2-cell embryos (93 to 100\%) developed to blastocysts, however only 34 to $44 \%$ of them from CD-1 strain embryos did. The ability of blastocysts to develop to fetuses was also lower in CD-1 strain females (15 to $22 \%$ ) than in F1 strain (23 to $48 \%$ ). Since the developmental ability to blastocysts of intact 2-cell embryos from the CD-1 strain females (90\%, 285/316, unpublished data) was not different from that of those from F1 females (90 to 95\%), embryos from CD-1 females might be more sensitive to the in vitro manipulation.

Monozygotic twin mice have been produced by 1) halving 2-cell or 8- to 16-cell embryos [2-6], or by 2) nuclear transfer to enucleated blastomeres of 2 -cell embryos and in vitro culture [10]. The success rate for the production of monozygotic twin mice for a single blastomere of a 2-cell embryo cultured in vitro and transferred to the recipients varied from $0[2,10]$ to $22 \%$ [6]. The present study suggests that the main reason for such variation is due to the difference of the female donor strain.

The difference in the method of removal of the zonae pellucidae of donor embryos did not affect the developmental ability of half embryos to blastocysts or to fetuses, in contrast to the report by Tsunoda and McLaren [4] in which the pronase treatment inhibits the development of half embry- os to young but not to blastocysts.

In the present study, half embryos were cultured in vitro as twin pairs in $20 \mu \mathrm{l}$ medium. Fewer mouse embryos cultured singly in 10 to $25 \mu \mathrm{lmi}$ crodrops are reported to develop to blastocysts and to young, than those cultured in groups $[12,13]$. However, development was improved by the addition of EGF, TGF- $\alpha$ or $\beta$ to the culture medium [12]. Harvey and Kayne [14] reported that IGF-1 increased the number of cells in the inner cell mass. However, in the present study, the addition of IGF1, EGF and TGF- $\beta$ did not stimulate the development of half embryos to blastocysts in vitro or to young after transfer. The concentration of each growth factor was determined according to the previous reports $[12,14]$, but the concentration suitable for the culture of half embryos remains to be determined.

In the F1 donor embryos, 7 to $29 \%$ in series 1 and 15 to $23 \%$ in series 2 developed to monozygotic twin mice. Since monozygotic twin mice obtained in experiment 2 had originated from different embryonic cytoplasm, similarities such as the timing of appearance of hair, eye opening and ear opening between twins [1] should be examined in detail.

\section{Acknowledgments}

Y. Kato and Y. Tsunoda were supported by grants from the Special Coordination Funds for Promoting Science and Technology from the Science and Technology Agency, the Ministry of Agriculture, Forestry and Fisheries (Biotechnology) and the Human Science Foundation. M. Wang was funded by the National Science Foundation of China (39360028) and the Educational Commission of Yunnan Province and People's Government of Yunnan Province. 


\section{References}

1. Gartner K, Baunack E. Is the similarity of monozygotic twins due to genetic factors alone? Nature 1981; 292: 646-647.

2. Fiser PS, Macpherson JW. Development of embryonic structures from isolated mouse blastomeres. Can J Anim Sci 1976; 56: 33-36.

3. Moustafa LA, Hahn J. Experimentelle erzeugung von identischen mausezwillingen. Dtsch Tierarztl Wochenschr 1978; 85: 242-244.

4. Tsunoda Y, McLaren A. Effect of various procedures on the viability of mouse embryos containing half the normal number of blastomeres. J Reprod Fertil 1983; 69: 315-322.

5. Nagashima H, Matsui K, Sawasaki T, Kano Y. Production of monozygotic mouse twins from microsurgically bisected morulae. J Reprod Fertil 1984; 70: 357-362.

6. Togashi M, Suzuki H, Miyai T, Okamoto MT. Production of monozygotic twins by splitting of 2cell stage embryos in mice. Jpn J Anim Reprod 1987; 33: 51-57.

7. Ozil JP. Production of identical twins by bisection of blastocysts in the cow. J Reprod Fertil 1983; 69: 463-468.

8. Willadsen SM, Godke RA. A simple procedure for the production of identical sheep twins. Vet Rec 1984; 114: 240-243.

9. Tsunoda $Y$, Tokunaga $T$, Sugie $T$, Katsumata $M$.
Production of monozygotic twins following the transfer of bisected embryos in the goats. Theriogenology 1985; 24: 337-342.

10. Tsunoda Y, Sugie T. Production of monozygotic twins in the mouse and goat. Jpn J Anim Reprod 1984; 30: 18-23.

11. Kono T,Tsunoda Y, Nakahara T. Production of identical twin and triplet mice by nuclear transplantation. J Exp Zool 1991; 257: 214-219.

12. Paria BC, Dey SK. Preimplantation embryo development in vitro: Cooperative interactions among embryos and role of growth factors. Proc Natl Acad Sci USA 1990; 87: 4756-4760.

13. Kato Y, Tsunoda Y. Effect of the culture density of mouse zygotes on the development in vitro and in vivo. Theriogenology 1994; 41: 1315-1322.

14. Harvey MB, Kaye PL. Insulin increases the cell number of the inner cell mass and stimulates morphological development of mouse blastocysts in vitro. Development 1990; 110: 963-967.

15. Fulton BP, Whittingham DG. Activation of mammalian oocytes by intracellular injection of calcium. Nature 1978; 273: 149-151.

16. Whittingham DG. Culture of mouse ova. J Reprod Fertil 1971; 14: 7-21.

17. Wolfe BA, Kraemer DC. Methods in bovine nuclear transfer. Theriogenology 1992; 37: 5-15. 